\title{
Source of seminal N-acetylglucosamine in Australian marsupials and further studies of free sugars of the marsupial prostate gland
}

\author{
J. C. Rodger and I. G. White \\ Department of Veterinary Physiology, University of Sydney, N.S.W. 2006, Australia
}

It has previously been shown that $\mathrm{N}$-acetylglucosamine occurs in the semen of some marsupials (Rodger \& White, 1974b, 1975) and that various other seminal sugars are produced by the prostate (Rodger \& White, 1974a). The present paper is a more comprehensive study of the sugars in marsupial prostates for clarification of the source of $\mathrm{N}$-acetylglucosamine in semen.

The tissues and fluids examined in the present study were collected and processed in the same manner as those studied previously; the biochemical assays have also been described (Rodger \& White, 1974a, 1975). All animals used were mature breeding males. The single specimen of a ringtail possum was collected during April 1973 in the metropolitan area of Sydney.

\section{Site of $N$-acetylglucosamine secretion}

In all the animals examined the prostate contained high levels of $\mathrm{N}$-acetylglucosamine, irrespective of the anatomy or segmentation of the gland (Table 1). The central prostatic segment was the major source of the sugar $(160-630 \mathrm{mg} / 100 \mathrm{~g}$ tissue) in the brush-tailed possum, red kangaroo, grey kangaroo and tammar wallaby. Both segments of the bandicoot prostate secreted high levels of $\mathrm{N}$-acetylglucosamine.

Only one specimen of ringtail possum was available, but cross-sectional slices of prostate midway along the length of the gland and comprising both posterior segments also contained N-acetylglucosamine although the prostate is anatomically different from the macropod-Trichosurus type (Rodger \& Hughes, 1973).

\section{Other sugars of the marsupial prostate}

Appreciable levels of free glucose occurred in the posterior segment of the prostate of the grey kangaroo, as it does in that of the red kangaroo (Rodger \& White, 1974a). In the prostates of all the other species and in the anterior and central segments of the grey kangaroo prostate glucose levels (Table 1) were equivalent to blood glucose concentrations. Glucose usually accounted for much of the anthrone-reactive material present in the prostate, but a considerable amount of other anthronereactive material occurred in the tammar wallaby and bandicoot prostates. Levels of resorcinolreactive material and fructose were very low (Table 1 ).

\section{Effect of hypophysectomy}

Four days after hypophysectomy of tammar wallabies (Hearn, 1974), the concentration of Nacetylglucosamine $(\mathrm{mg} / 100 \mathrm{~g})$ in the central prostatic segment, the major source of the seminal sugar in this species, had been reduced to $90 \cdot 4$, a third of control values (263.0). After 60 days, values of $38 \cdot 4,42 \cdot 4$ and $69 \cdot 0$ were obtained. There were no changes in glucose- and anthrone-reactive carbohydrate levels in any of the three segments.

\section{Semen of the brush-tailed possum}

Possum seminal plasma contained $153 \mathrm{mg} \mathrm{N}$-acetylglucosamine/100 g. Anthrone-reactive sugar amounted to $10-20 \mathrm{mg} / 100 \mathrm{~g}$ and glucose $1-5 \mathrm{mg} / 100 \mathrm{~g}$ (glucose oxidase method) in seminal plasma. Ejaculates from three animals were analysed. 
Table 1. Mean ( \pm S.E.M.) concentrations ( $\mathrm{mg} / 100 \mathrm{~g}$ tissue) of sugars in the prostate glands of marsupials

\begin{tabular}{|c|c|c|c|c|c|c|}
\hline Species & $\begin{array}{l}\text { Segment of } \\
\text { gland }\end{array}$ & $\begin{array}{c}\text { N-acetylglucosamine } \\
\text { (Morgan-Elson } \\
\text { reagent) }\end{array}$ & Glucose & $\begin{array}{l}\text { Anthrone- } \\
\text { reactive } \\
\text { material } \\
\text { (as glucose) }\end{array}$ & $\begin{array}{l}\text { Resorcinol- } \\
\text { reactive } \\
\text { material } \\
\text { (as fructose) }\end{array}$ & Fructose \\
\hline $\begin{array}{l}\text { Brush-tailed possum } \$ \\
\text { (Trichosurus vulpecula) }\end{array}$ & $\begin{array}{l}\text { Anterior } \\
\text { Central } \\
\text { Posterior }\end{array}$ & $\begin{array}{c}37 \pm 5.4 \\
161 \pm 20 \cdot 1 \\
23 \pm 4.7\end{array}$ & $\begin{array}{c}22 \pm 2 \cdot 9^{*} \\
6 \pm 0.8 \\
10 \pm 0 \cdot 8\end{array}$ & $\begin{array}{l}54 \pm 4 \cdot 8 \\
15 \pm 1 \cdot 7 \\
29 \pm 4 \cdot 6\end{array}$ & $\begin{array}{r}4 \\
2 \\
51\end{array}$ & $\begin{array}{l}2^{*} \\
1 \\
1\end{array}$ \\
\hline $\begin{array}{l}\text { Ringtail possum } \\
\text { (Pseudocheirus } \\
\text { peregrinus) }\end{array}$ & Posterior 1,2 & 461 & & & & \\
\hline $\begin{array}{l}\text { Red kangaroo } \$ \\
\quad(\text { Megaleia rufa })\end{array}$ & $\begin{array}{l}\text { Anterior } \\
\text { Central } \\
\text { Posterior }\end{array}$ & $\begin{array}{c}97 \pm 26.8 \\
630 \pm 70 \cdot 9 \\
10 \pm 2 \cdot 2\end{array}$ & $\begin{array}{c}10 \pm 0 \cdot 7^{*} \\
7 \pm 1 \cdot 0 \\
92 \pm 11 \cdot 1\end{array}$ & $\begin{array}{c}23 \pm 3 \cdot 8 \\
46 \pm 6 \cdot 0 \\
136 \pm 14 \cdot 5\end{array}$ & $\begin{array}{l}4 \\
7 \\
9\end{array}$ & $\begin{array}{l}2 * \\
1 \\
3\end{array}$ \\
\hline $\begin{array}{l}\text { Grey kangaroo } \\
\quad \text { (Macropus giganteus) }\end{array}$ & $\begin{array}{l}\text { Anterior } \\
\text { Central } \\
\text { Posterior }\end{array}$ & $\begin{array}{c}112 \pm 23 \cdot 8 \\
465 \pm 56 \cdot 7 \\
27 \pm 7 \cdot 9\end{array}$ & $\begin{array}{c}36 \pm 14 \cdot 7^{*} \\
22 \pm 2 \cdot 2 \\
139 \pm 29 \cdot 1\end{array}$ & $\begin{array}{c}58 \pm 14 \cdot 4 \\
63 \pm 6 \cdot 8 \\
224 \pm 40 \cdot 0\end{array}$ & $\begin{array}{l}3 \\
4 \\
6\end{array}$ & $\begin{array}{l}3 * \\
3 \\
3\end{array}$ \\
\hline $\begin{array}{l}\text { Tammar wallaby } \\
\text { (Macropus eugenii) }\end{array}$ & $\begin{array}{l}\text { Anterior } \\
\text { Central } \\
\text { Posterior }\end{array}$ & $\begin{array}{c}63 \pm 16 \cdot 7 \\
580 \pm 121 \cdot 8 \\
25 \pm 4 \cdot 9\end{array}$ & $\begin{array}{l}37 \pm 4 \cdot 0 \dagger \\
34 \pm 5 \cdot 4 \\
38 \pm 6 \cdot 7\end{array}$ & $\begin{array}{r}72 \pm 14 \cdot 7 \\
123 \pm 19 \cdot 8 \\
99 \pm 23 \cdot 6\end{array}$ & & \\
\hline $\begin{array}{l}\text { Long-nosed bandicoot } \\
\text { (Perameles nasuta) }\end{array}$ & $\begin{array}{l}\text { Ventral } \\
\text { Dorsal } \\
\text { Secretiont }\end{array}$ & $\begin{array}{l}507 \pm 104 \cdot 6 \\
258 \pm 34 \cdot 6 \\
197\end{array}$ & $\begin{array}{l}57 \pm 17 \cdot 5 \uparrow \\
66 \pm 13 \cdot 7 \\
30\end{array}$ & $\begin{array}{c}261 \pm 16.4 \\
186 \pm 34.8 \\
99\end{array}$ & & \\
\hline $\begin{array}{l}\text { Short-nosed bandicoot } 1 \\
\text { (Isoodon macrourus) }\end{array}$ & $\begin{array}{l}\text { Ventral } \\
\text { Dorsal }\end{array}$ & $\begin{array}{l}711 \\
278\end{array}$ & $\begin{array}{l}36 \dagger \\
56\end{array}$ & $\begin{array}{l}289 \\
182\end{array}$ & & \\
\hline
\end{tabular}

* Glucose and fructose measured by the enzymatic hexokinase method.

$\uparrow$ Glucose measured by the enzymatic glucose oxidase method.

$\ddagger$ Fluid which flowed from one gland when dissected.

$\S$ Glucose, anthrone-reactive material, resorcinol-reactive material and fructose figures from Rodger \& White (1974a).

T Single observation.

\section{Discussion}

$\mathrm{N}$-acetylglucosamine appears to be the major free sugar of the semen and prostate gland tissue of Australian marsupials. It occurs in high concentrations in the semen, from $100 \mathrm{mg} / 100 \mathrm{~g}$ up to 900 $\mathrm{mg} / 100 \mathrm{~g}$, and at similar levels in the central segment of the prostate gland of brush-tailed possums, tammar wallabies and red and grey kangaroos and both segments of the bandicoot prostate. The amount of $\mathrm{N}$-acetylglucosamine is of the same order as that of fructose in the semen and accessory glands of most eutherian species examined (Mann, 1964). Fructose is probably absent from the semen of Australian marsupials or present in only trace amounts. It has never been detected by paper chromatography (Rodger \& White, 1974b) and the trace amounts indicated in Table 1 are below the level of reliability of the method employed and may be due to inherent drift in the assay system. Examination of further marsupial species may reveal exceptions to this broad statement but the presence of high levels of $\mathrm{N}$-acetylglucosamine in all of the species examined thus far indicates that, just as fructose is the characteristic sugar of eutherian semen, $\mathrm{N}$-acetylglucosamine is the characteristic sugar of the semen and prostate gland of Australian marsupials.

The response of the tammar wallaby prostate to hypophysectomy was predictable in that removal of pituitary gonadotrophins resulted in a decline in $\mathrm{N}$-acetylglucosamine concentration in the glandular tissue of the central segment. This effect is presumably mediated via reduced androgen secretion from the testes. By 60 days after hypophysectomy, $\mathrm{N}$-acetylglucosamine concentrations had fallen to only slightly below the 4-day figures and were of the same order as those found in the other segments of the prostate of normal breeding animals (Table 1). Thus although there appears to be pituitary control of $\mathrm{N}$-acetylglucosamine secretion by the central prostate segment in the tammar wallaby, there is a low level of $\mathrm{N}$-acetylglucosamine production in all three segments which is 
independent of pituitary control. Glucose concentrations did not change after hypophysectomy, indicating that the low levels of glucose found in the prostate of the tammar (Table 1) are probably reflecting blood glucose levels and are not under the control of sex hormones.

It would be of considerable interest to compare the effects of gonadotrophin and androgen deprivation on the prostate gland of the red and grey kangaroo with these observations in the tammar wallaby, as the prostates of both kangaroo species secrete high levels of glucose as well as $\mathrm{N}$-acetylglucosamine. If the glucose is, as these observations would suggest, involved directly in reproductive function, endocrine regulation by sex hormones would be expected. All three species are ruminantlike herbivores and as such have low blood glucose levels, $25-80 \mathrm{mg} / 100 \mathrm{~g}$ (Griffiths, McIntosh \& Leckie 1969; Renfree 1970). In contrast, the possum, a non-ruminant herbivore which has high blood glucose levels around $120 \mathrm{mg} / 100 \mathrm{~g}$ (Adams \& Bolliger, 1954), has a similar prostatic glucose pattern to the tammar wallaby. Species differences in blood glucose levels cannot apparently be used to explain these differences in seminal and prostatic glucose.

We are indebted to Professor C. W. Emmens for his interest and advice, and Dr J. P. Hearn, Department of Zoology, Australian National University, Canberra, for prostates from hypophysectomized tammars. Officers of the N.S.W. National Parks and Wildlife Service and Mr P. Davis, 'Brookland Park', Kangaroo Island, South Australia, assisted in obtaining material. The work was financed in part by the Australian Research Grants Committee.

\section{References}

ADAMS, D.M. \& Bolliger, A. (1954) Observations on carbohydrate metabolism and alloxan diabetes in a marsupial (Trichosurus vulpecula). Aust. J. exp. Biol. med. Sci. 32, 101-111.

GRIfFITHS, M., McINTOSH, D.L. \& LeckIe, R.M.C. (1969) The effects of cortisone on nitrogen balance and glucose metabolism in diabetic and normal kangaroos, sheep and rabbits. J. Endocr. 44, 112.

Hearn, J.P. (1974) The pituitary gland and implantation in the tammar wallaby, Macropus eugenii.J. Reprod. Fert. 39, 235-241.

MANn, T. (1964) The Biochemistry of Semen and of the Male Reproductive Tract. Methuen, London.

Renfree, M.B. (1970) Protein, amino acids and glucose in the yolk-sac fluids and maternal blood sera of the tammar wallaby, Macropus eugenii (Desmarest). J. Reprod. Fert. 22, 483-492.

Rodger, J.C. \& Hughes, R.L. (1973) Studies of the accessory glands of male marsupials. Aust. J. Zool. 21, 303-320.

RoDGER, J.C. \& WhITE, I.G. (1974a) Carbohydrates of the prostate of two Australian marsupials, Trichosurus vulpecula and Megaleia rufa.J. Reprod. Fert. 39, 267-273.

RoDGER, J.C. \& WhITE, I.G. (1974b) Free N-acetylglucosamine in marsupial semen. J. Reprod. Fert. 39, 383-386.

Rodger, J.C. \& White, I.G. (1975) Electroejaculation of Australian marsupials and analyses of the sugars in the seminal plasma from three macropod species. J. Reprod. Fert. 43, 233-239.

Received 1 September 1975 